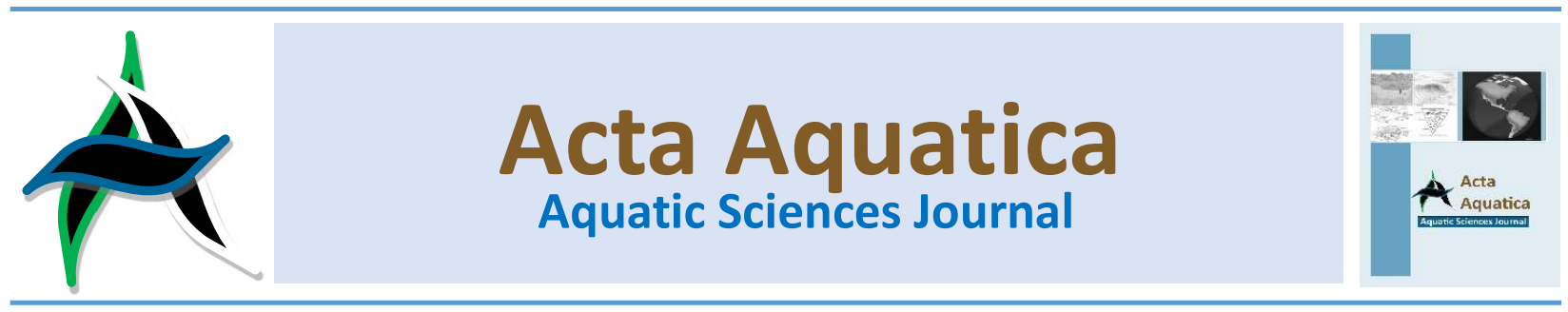

\title{
Contribution to the current list of Nitzschia species (Bacillariophyceae) in Malaysia
}

\author{
Suriyanti Su Nyun Pau ${ }^{*}$, Dzulhelmi Muhammad Nasir ${ }^{\mathrm{b}}$ and Gires Usup ${ }^{\mathrm{a}}$ \\ ${ }^{a}$ Department of Earth Sciences and Environment, Faculty of Science and Technology, Universiti Kebangsaan Malaysia, 43600 Bangi, Selangor, Malaysia. \\ ${ }^{b}$ Malaysian Palm Oil Board, 6, Persiaran INstitusi, Bandar Baru Bangi, 43000 Kajang, Selangor, Malaysia.
}

\begin{abstract}
Current occurrence of Nitzschia Hassall from marine and freshwater environment in Malaysia is compiled from current and previously published materials. Phytoplankton was collected using a $20 \mu \mathrm{m}$ plankton net from waterfronts of Peninsular Malaysia and Borneo. Some Nitzschia cells were successfully isolated and established into clonal cultures. For morphology observation, organic matters of the net samples and cultures were oxidized and removed through acid treatment. Cleaned specimens were observed using light and electron microscopes. The morphology of the Nitzschia cells was described and micrographs are included. In addition to current field sampling, Nitzschia spp. records and distributions in Malaysia had also been compiled from secondary data. Sources of references whereby the Nitzschia species were listed in this article were cited accordingly. This article compiles a total of 11 Nitzschia spp. found in Malaysia including a few revisions and new records. This article could serve as an important reference for Nitzschia taxonomic and distributional study particularly in tropical region.
\end{abstract}

Keywords: distribution, morphology, taxonomy, tropical

\section{Introduction}

Diatoms of the genus Nitzschia Hassall 1845 are highly diversified. They represent one of the dominant genera in diatom assemblages (Kaczmarska et al., 1986) comprising both planktonic and benthic species (Lundholm and Moestrup, 2000). There have been very few studies on Nitzschia occurrence and distributions in Malaysian water. This pennate diatom has important roles as one of the primary producers in aquatic ecosystem, water quality bioindicators (Wan-Maznah and Mansor, 2002; Trobajo et al., 2009) and as live feeds in aquaculture farms due to its richness in fatty acids (Chu et al., 1996; Shi et al., 2008). Local phytoplankton surveys (Shamsudin, 1990; Aishah, 2005; Saifullah et al., 2014) and physiological studies of Nitzschia (Chu et al., 1996; Wen and Chen, 2001) were lacking in morphological descriptions and/ or micrographic evidences. Micrographs are essential for diatom identification particularly in the genus Nitzschia as this diatom could be easily mistaken as other diatom species and vice versa. Species identification merely through descriptive and diagnostic references without the aid of micrographs or illustrations could be ambiguous. For instance, linear shapes might look lanceolate by a different observer. Therefore, it is more preferable to document the descriptions of Nitzschia spp. with inclusion of its micrographs.

* Corresponding: Department of Earth Sciences and Environment, Faculty of Science and Technology, Universiti Kebangsaan Malaysia, 43600 Bangi, Selangor, Malaysia.

e-mail: suriyanti@ukm.edu.my
The genus Nitzschia is very complicated taxonomically, as there are hundreds of described species worldwide. This genus was previously subdivided by Grunow (1862) into subgroups, which corresponded with the frustule's characteristics. Some modifications have been made to the divisions by a number of authorities (refer to Guiry and Guiry, 2014), yet many of the original descriptions remained. The groupings of Nitzschia spp. in this article was mainly referenced from the revision made to the Nitzschia sections by Mann (1978) whereby he summarized into 17. Nonetheless, progressive research in the genus had led to the establishments of new genera from the previous sections (refer to Guiry and Guiry, 2014). Current groupings that are being used comprise the sections of Dubiae Hustedt, Perrya grunow, Insignes grunow, Epithemioideae grunow, Spathulatae grunow, Nitzschia grunow (syn. = Sigmoidea sensu Hustedt), Lineares grunow, Lanceolatae grunow and Nitzschiella grunow. Nonetheless, these sections could be used interchangeably amongst taxonomists.

This article compiles Nitzschia occurrence record in Malaysian freshwater and marine water via sample collections and extraction from published materials. This study is important for Nitzschia taxa biogeographic and taxonomic research particularly in tropical waters.

\section{Materials and Methods}

\subsection{Sample collection and culture materials}

Phytoplankton samples were collected from seawater of Peninsular and East Malaysia (Fig. 1) using a 20 ?m plankton net. Net samples were divided into two portions. One part was preserved in Lugol's iodine for light microscopy, acid-treatment and storage. Another portion of live sample was brought back to 
the laboratory for single-cell isolation. Culturing is required to obtain multiple cells for identification purposes. Healthily divided cells of 30 total isolates were transferred into culture tubes containing silica-enriched SWII medium (Iwasaki, 1961) and maintained under $14: 10$ hour of light: dark cycle at $25^{\circ} \mathrm{C}$.

\subsection{Sample preparation.}

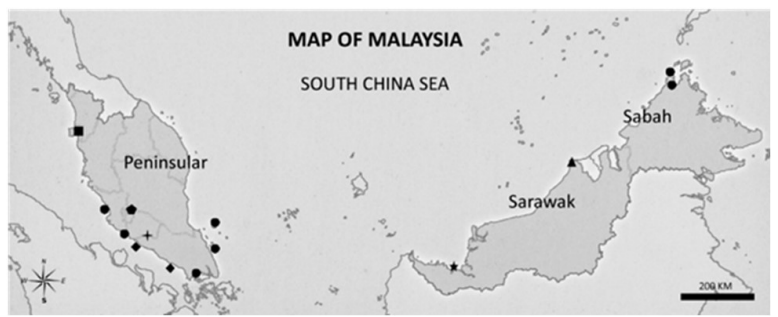

Figure 1. Map of Malaysia. The locations where samples were collected in present study (@); Nather- Khan (1990) [ ] Shamsudin (1990) [ ]; Aishah and Nooraini (1994) [-]; Wan-Maznah and Mansor (2002) [ + ]; Fareha et al. (2011) [ $\star$ ] and Shaifullah et al. (2014) [ [A]

The organic matters of cells were removed according to the procedures in Renberg (1990). Preserved samples and cultured cells were harvested by centrifugation at $8000 \mathrm{rpm}$ for 10 minutes and media removed. The cells were oxidized in Hydrogen peroxide $(30 \%)$ at $85{ }^{\circ} \mathrm{C}$ for 2 a 3 hours. After organic matters have been removed, the samples were resuspended with $10 \%$ hydrochloric acid and soaked for several days at room temperature. The samples were agitated gently every few hours to minimize breakage. After the treatment, cells were rinsed 2 ? 3 times with distilled water and stored in $70 \%$ ethanol.

\subsection{Light and electron microscopy}

Both living cells and cleaned specimens were observed under a light microscope and measured. A minimum of 30 living cells were randomly picked from the first batch of each culture for the measurement. Cleaned specimens were mounted on glass slides using Naphrax mountant and viewed using light microscope (Olympus BX51TF, Japan) equipped with a built-in camera (Olympus U-TV1x, Japan). The valve dimensions were measured by AnalySIS LS Professional software. For electron microscopy, samples were dried on cover slips and mounted on a stub for gold-palladium coating. Samples were viewed using scanning electron microscope (Leo $1450 \mathrm{VP}$, United Kingdom). For transmission electron microscopy (Philips CM12, Netherland), the samples were mounted on formvar-coated copper grids for viewing.

\subsection{Morphology identification}

The characteristics observed for species identification were valve outlines, cell dimensions, fibulae and striae densities, raphe systems and poroids. Literatures referenced for identification were included in each species description. For secondary data of local records, published articles from previous studies and books were collected and compiled.

\section{Result and Discussion}

Seven Nitzschia spp. have been identified from total 30 cultures obtained from 7 locations throughout Malaysia in present study (Table 1). Twelve species were retrieved from secondary data. Nine out of 12 species in the secondary data had been misidentified and were therefore revised accordingly (Table 2). The most frequently occurring Nitzschia spp. in Malaysia is from the section Lanceolatae (seven species). Altogether, this study compiled at least 11 Nitzschia spp. from Malaysian water (Table 1). These are inclusive of four new records and three revised identities. Detailed descriptions of these species are presented.

\subsection{Section Lanceolatae}

\subsubsection{N. amabilis Suzuki 2010}

Synonym : N. laevis Hustedt 1939

Local record : Present study, Fig. 2A-E

Reference(s) : Hustedt (1939); Suzuki et al. (2010); Rivera and Cruces (2011)

Description : Cell broadly lanceolate, constricted in the middle (Fig. 2A); length 14.6 - $18.9 \mu \mathrm{m}$; width $3.5-5.6 \mu \mathrm{m}$; central nodule visible under light microscope (Fig. 2B, arrow); irregularly spaced and more widely separated in the middle of the fibulae (Fig. 2C-D), 9-10 in $10 \mu \mathrm{m}$; striae 41 in $10 \mu \mathrm{m}$; 1 row of poroid, 5 in $1 \mu \mathrm{m}$; pore-like raphe ending from external view (Fig. 2E); biseriate copulae.

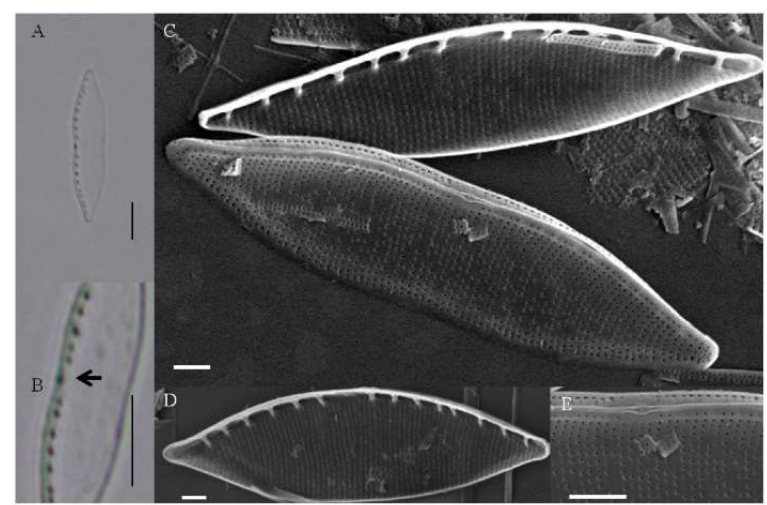

Figure 2. LM and SEM micrographs of $\mathrm{N}$. amabilis isolate TK47. LM (A-B). (A) Whole valve with slight indentation in the middle; (B) Fibulae appear like dots along the valve margin with central interspace. Central nodule visible (arrow). Scale bar $=10$ [m. SEM (C-E). (C) External and internal view of the valve; (D) Internal view of the valve showing the irregularly spaced fibulae and larger central interspace (E) porelike central nodule is observable from the external view. Scale bar $=1 \mu \mathrm{m}$.

\subsubsection{N. frustulum (Kutzing) Grunow 1880}

Local record : Present study, Fig. 3A-E

Reference(s) : Cleve and Grunow (1880); Reimer (1954); Mann (1978); Trobajo et al. (2013)

Description : Outline linear-lanceolate, two yellow-brown chloroplasts (Fig. 3A), rectangular in girdle view (Fig. 3B); length $12.0-14.0 \mu \mathrm{m}$; width $3.0-4.0 \mu \mathrm{m}$; slightly constricted in the middle (Fig. 3C); fibulae $14-15$ in $10 \mu \mathrm{m}$; central interspace present (3C); striae 52 in $10 \mu \mathrm{m}$; 1 row of poroid, 6 in $1 \mu \mathrm{m}$, poroids in the raphe canal (Fig. 3C-D); copulae has two rows of poroid (Fig. 3E).

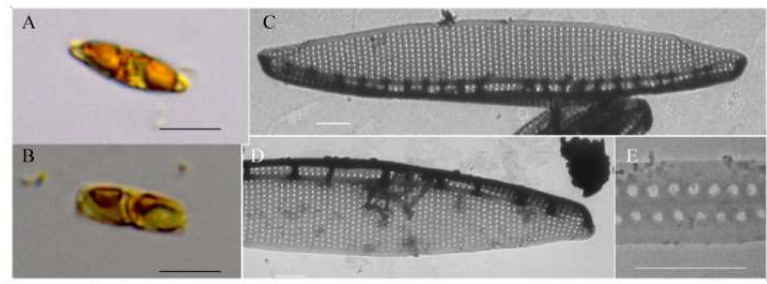

Figure 3. LM and TEM micrographs of $N$. frustulum isolate KD92. LM (A-B). (A) Whole cell showing two large chloroplasts; (B) rectangular in girdle view, chloroplasts appressed to the girdle. Scale bar $=10$ ?m. TEM (C-E). (C) Internal view of the valve showing poroids in the raphe canal. Fibulae are irregularly spaced and more widely 
separated in the middle; (D) slanted valve end. (E) two rows of poroid in the cingulum. Scale bar $=1 \mu \mathrm{m}$

\subsubsection{N. inconspicua Grunow 1862}

Local record : Present study, Fig. 4A ? E

Reference(s) : Grunow (1862); Kociolek (2011a); Trobajo et al. (2013)

Description : Two yellow brown chloroplasts at each pole (Fig. 4A); valve outline lanceolate (Fig. 4B Q? C); length 12.1 - 14.4 $\mu \mathrm{m}$; width $2.0-3.2 \mu \mathrm{m}$; fibulae $14-15$ in $10 \mu \mathrm{m}$; central interspace absent, 'nitzschioid' symmetry; interstriae are broad; striae 31 in $10 \mu \mathrm{m}$; 1 row of round poroids, 4 in $1 \mu \mathrm{m}$; more oval shape poroids along the raphe; raphe highly eccentric, terminal fissures hook towards the same side of valve (Fig. 4C - D); central raphe ending present, (Fig. 4E, arrow).

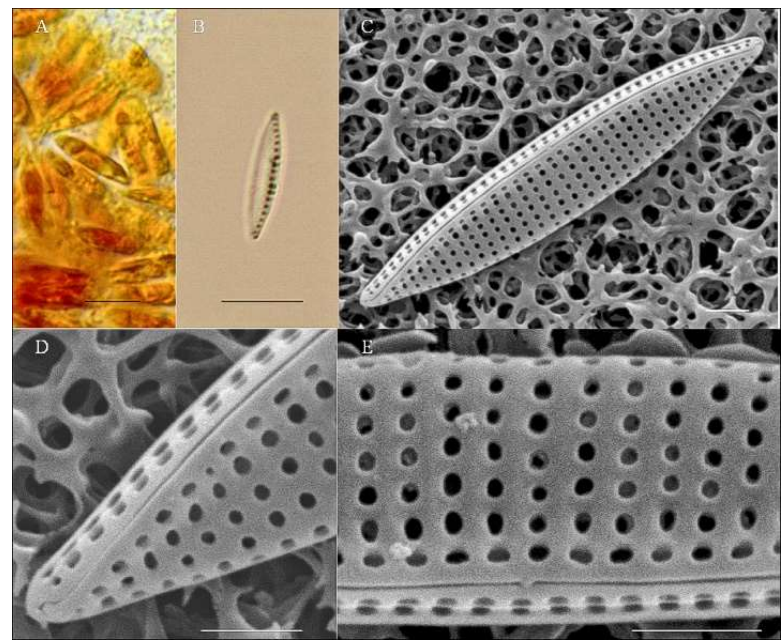

Figure 4. LM and SEM of N. inconspicua isolate TOB54. LM (A-B). (A) Whole cell with yellow-brown chloroplasts; (B) Internal view of a acid-cleaned valve, without large central interspace of fibulae. Scale bar $=10$ ?m. SEM (C-E). (C) External view of the valve, showing circular and relatively large poroids with uniform arrangement; (D) pointed end with terminal fissure hooked towards the valve face; (E) Raphe slit is interrupted in the middle by the thickening of silica, resulting in a simple type of central end. Scale bar $=1 \mu \mathrm{m}$

\subsubsection{N. lanceolata Smith 1853}

Local record : Shamsudin (1990), p. 195, Fig. 65

Reference(s) : Smith (1853); Chin et al. (1986); Shamsudin (1990)

Description : Lanceolate valve outline, enlarged centre, prolonged apices. Strong plicate is observed in girdle view. Valve length varied from $20.0-200.0 \mu \mathrm{m}$ and width $4.0-17.0 \mu \mathrm{m}$.

\subsubsection{N. palea (Kutzing) Smith 1856}

Local record : Nather-Khan (1990), figure not available; WanMaznah and Mansor (2002), figure not available

Reference(s) : Smith (1856); Foged (1971); Mann (1978); Torgan et al. (2009)

Description : Lanceolate outline; length 21.0 - $48.0 \mu \mathrm{m}$; width $4.0-5.0 \mu \mathrm{m}$; fibulae density lower than striae; central interspace absent.

\subsubsection{N. pusilla Grunow 1862}

Local record : Fareha et al. (2011), p 17, Fig. 5(H) (as N. cf. amphibia); Present study, Fig. 5A-5C.

Reference(s) : Grunow (1862); Coste and Ricard (1981); Trobajo et al. (2013)

Description : Outline linear-lanceolate to elliptical; broadly rounded apices (Fig. 5A); length 7.2 - $9.7 \mu \mathrm{m}$; width $1.8-3.5 \mu \mathrm{m}$; fibulae $>9$ in $10 \mu \mathrm{m}$, rectangular, irregularly spaced (Fig. 5B); striae > 37 in $10 \mu \mathrm{m}$; longitudinally curved along the valve (Fig. 5C); 1 row of poroid, $9-10$ in $1 \mu \mathrm{m}$; central interspace absent.

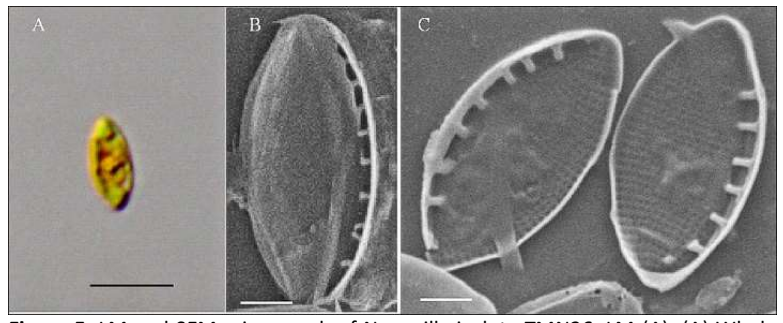

Figure 5. LM and SEM micrograph of $N$. pusilla isolate TMN26. LM (A). (A) Whole valve of the cell. The outline is lanceolate with broadly rounded apices. Scale bar 10 ? $\mathrm{m}$. SEM (B-C). (B) Internal view of the valves. The fibulae arrangement is irregular. Central interspace is absent. (C) The striae are uniseriate and slowly radiate towards the apices. Scale bar $=1 \mu \mathrm{m}$

\subsection{The section Nitzschiella}

\subsubsection{N. longissima (Brebisson) Ralfs 1861}

Local record : Shamsudin (1990); Aishah (2005), figure not available; Fareha et al. (2011), p. 17, Fig. 5(A - D)

Reference(s) : Pritchard (1861); Hasle and Syvertsen 1997; Shamsudin (1990); Fareha et al. (2011)

Description : Valve fusiform in the central part, extend to very long projection (rostra; length $125.0-450.0 \mu$ m; width 4.4 $-8.0 \mu \mathrm{m}$; fibulae $6-14$ in $10 \mu \mathrm{m}$; striae $48-60$ in $10 \mu \mathrm{m}$; raphe strongly eccentric; central interspace present.

\subsection{The section Nitzschia}

\subsubsection{N. Iorenziana Grunow 1880}

Local record : Shamsudin (1990), p. 167, Fig. 8.161; Present study, Fig. 6A - E.

Reference(s) : Cleve and Moller (1879); Chin et al. (1986); Shamsudin (1990)

Description : Very abundant in mangrove mud; solitary cells and weakly silicified; two chloroplasts separated by a nucleus at the centre (Fig. 6A); valve sigmoid in valve and girdle views (Fig. $6 \mathrm{~A}$ ? B); length $34.4-37.6 \mu \mathrm{m}$; width $2.8-4.4$ ?m; apices capitate; coarse fibulae without interspace in the middle (Fig. 6C - D), 16 in $10 \mu \mathrm{m}$; raphe highly eccentric at the valve margin; raphe slit continuous; raised raphe canal; fine striae (Fig. 6E) ,65 in $10 \mu \mathrm{m}$; interstriae are more raised in the internal valve compared to the external; 1 row of round poroids, only discernable from internal views; simple-type perforation; 7-8 in $1 \mu \mathrm{m}$; two rows of poroid in the girdle bands.

\subsubsection{N. paeneperpetua Mann 1981}

Local record : Present study, Fig. 7A - F

Reference(s) : Mann (1981) 
Description : Very long valve, sigmoid in valve view (Fig. 7A), linear-sigmoid in girdle; length 373.4-835.0 $\mu \mathrm{m}$; width 6.5-10.1 $\mu \mathrm{m}$; fibulae $6.5-8$ in $10 \mu \mathrm{m}$, regularly spaced (Fig. 7B); striae 20 -27 ; 1 row of poroid, $2-3$ in $1 \mu \mathrm{m}$; central interspace present (Fig. 7C, with central nodule (Fig. 7D); striae pattern irregularity (Fig. 7E); single poroid row in the copulae (Fig. 7F).

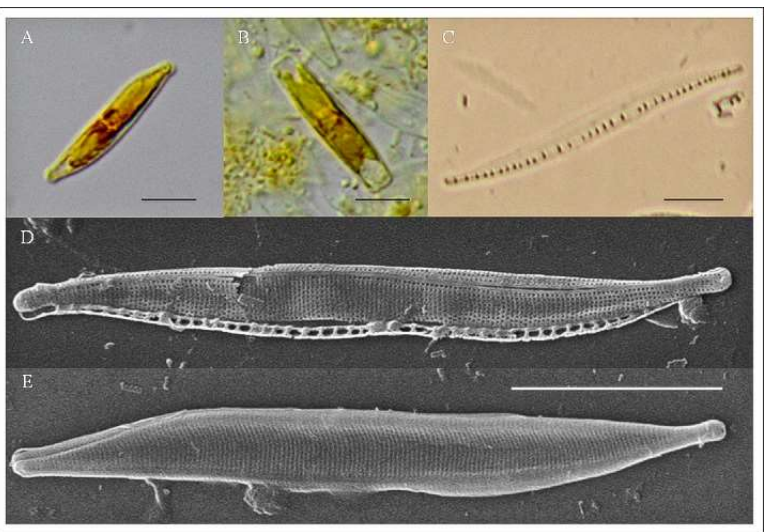

Figure 6. LM and SEM of N. Iorenziana isolate KS55. LM (A-C). (A) Valve view of the cell showing large chloroplasts; (B) girdle view of a cell; (C) Fibulae discernable under light microscopy, without central interspace. SEM (D-E). (D) internal view of valve showing the fibulae; $(E)$ external view of valve with very fine striation. Scale bar $=10 \mu \mathrm{m}$.

\subsubsection{N. scalpelliformis Grunow 1880}

Synonym : N. obtusa var. scalpelliformis (Grunow) Grunow 1881

Local record : Shamsudin (1990), p. 200, Figure 84; Fareha et al. (2011), p. 17, Fig. 5(E-F)

Reference(s) : Cleve and Grunow (1880); Foged (1971); Mann (1978)

Description : Cell strongly sigmoid in valve and girdle view, body is long and narrow with bluntly rounded apices; length 24.0 $-63.8 \mu \mathrm{m}$, width $4.5-8.0 \mu \mathrm{m} ; 6-9$ fibulae in $10 \mu \mathrm{m} ; 20$ striae in $10 \mu \mathrm{m}$.

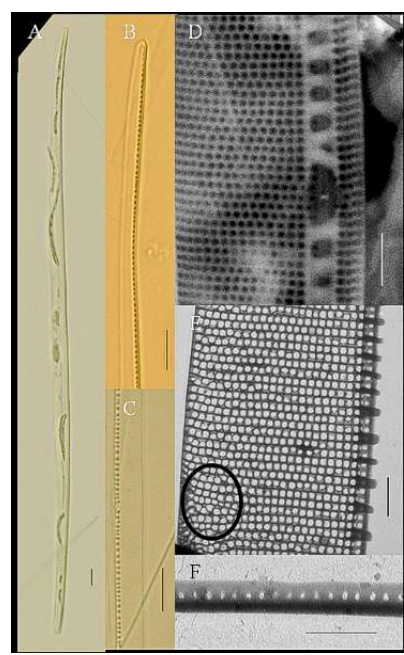

Figure 7. LM, SEM and TEM of $N$. paeneperpetua isolate PD1. LM (A-C), (A) Whole valve of the cell; (B) end of the valve with regularly spaced fibulae; (C) central interspace. Scale bar $10 \mu \mathrm{m}$. SEM (D). (D) central nodule present. Scale bar $2 \mu \mathrm{m}$. TEM (E-F). (E) poroids in the raphe canal and irregular striae arrangement (circle); (F) copulae is lined by single row of poroid. Scale bar $=2 \mu \mathrm{m}$.

\subsubsection{N. sigma Kutzing (Smith) 1853}

Local record : Shamsudin (1990), p. 167, Fig. 8.157, Fig. 8.158; Aishah and Nooraida (1994), p. 81, Plate 2 Fig. 36; Saifullah et al. (2014), p918; Present study; Fig. 8A - G

Reference(s) : Smith (1853); Mann (1978); Chin et al. (1986); Aishah and Nooraida (1994); Kociolek (2011b)

Description : Cell sigmoid in valve and girdle view (Fig. 8A), length $136.0-139.8 \mu \mathrm{m}$; width $5.1-8.0 \mu \mathrm{m}$; valve shallow, fibulae 9 in $10 \mu \mathrm{m}$; fine striae; more than 40 in $10 \mu \mathrm{m}$ (Fig. 8B C); 1 row of poroid, $4-5$ in $1 \mu \mathrm{m}$; imperforated apices, hookedtype external terminal end (Fig. 8D); internal raphe ends in helictoglossa (Fig. 8E); raphe strongly eccentric; central raphe ending absent (Fig. 8F), single row of poroid in copulae (Fig. 8G).

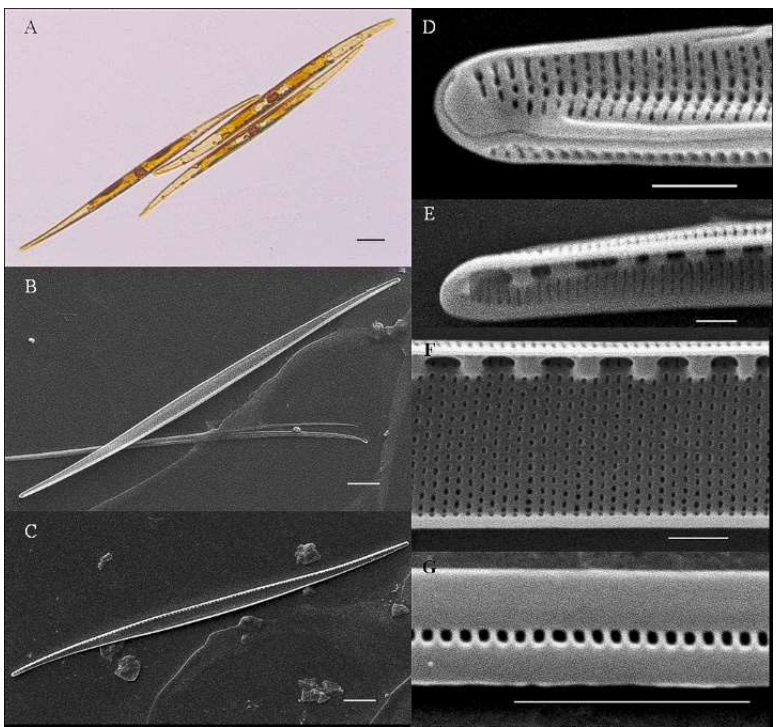

Figure 8. LM and SEM of N. sigma isolate KS58. LM (A). (A) Lugol preserved cell showing the plastids. Scale bar $=10$ ? $\mathrm{m}$. SEM (B-F). (B) external view of the valve with very fine striation; $(C)$ internal view of the valve showing the fibulae at the valve margin; (D) external end with terminal fissure strongly hooked towards the valve, no perforation at the end; $(E)$ internal raphe end with helictoglossa (arrow); (F) regularly spaced fibulae and equidistance in the middle; $(\mathrm{G})$ single row of poroid in the cingulum. Scale bar $=1 \mu \mathrm{m}$

Tabel 1

List of Nitzschia spp. recorded in Malaysia from present study and secondary data.

\begin{tabular}{|c|c|c|c|c|c|c|c|c|c|}
\hline Species & 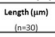 & 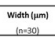 & 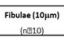 & 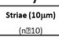 & 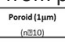 & a & Lecalty & Hablat & 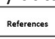 \\
\hline 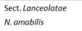 & 14.6-18.9 & 3.5 .5 .6 & & 41 & 5 & . & Teluvk kumbar, ahor & A & $\varepsilon$ \\
\hline & $\begin{array}{l}12.0-140 \\
0.12014\end{array}$ & 3.040 & 14-15 & 52 & 6 & $\pi$ & 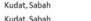 & A & $\varepsilon$ \\
\hline 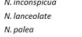 & 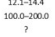 & $\begin{array}{l}20.32 \\
6.0 .080 \\
7\end{array}$ & ? & 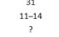 & ? & 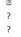 & 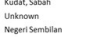 & $\begin{array}{l}A \\
A \\
B\end{array}$ & $\begin{array}{c}\xi \\
\xi \\
6, H\end{array}$ \\
\hline 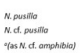 & $\begin{array}{l}7.2 .9 .7 \\
8.5\end{array}$ & $\begin{array}{c}1.8 .35 \\
2.7 \\
2.7\end{array}$ & 然 & 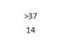 & ? & . & 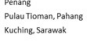 & $\begin{array}{l}A \\
c\end{array}$ & 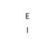 \\
\hline 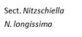 & 4070 & 8.0 & 11 & ${ }^{43}$ & ? & $?$ & 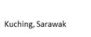 & c & 1 \\
\hline 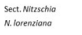 & $34.4-37.6$ & $2.8-44$ & 16 & 65 & $7-8$ & 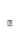 & Kusula Selorgax & . & $\varepsilon$ \\
\hline 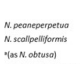 & $\begin{array}{l}790-4000 \\
3734.225 .5 \\
638\end{array}$ & $\begin{array}{c}6.0 \\
6510.1 \\
5.6\end{array}$ & $?$ & $\begin{array}{l}\begin{array}{l}14-15 \\
20 \\
20\end{array} \\
20\end{array}$ & $\begin{array}{l}2-3 \\
3-4\end{array}$ & ; & 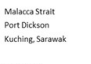 & $\begin{array}{l}\hat{A} \\
\hat{c}\end{array}$ & ; \\
\hline 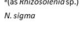 & $\begin{array}{c}336.0-139.8 \\
?\end{array}$ & $\begin{array}{c}3.180 \\
? \\
?\end{array}$ & ? & $\begin{array}{c}3 \\
3 \\
?\end{array}$ & a-5 & $?$ & 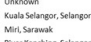 & $\begin{array}{l}A \\
0 \\
0\end{array}$ & $\therefore$ \\
\hline
\end{tabular}

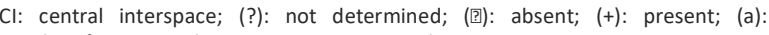
misidentification; Habitat: A: Marine; B: Freshwater; C: Estuarine; D: Mangrove; References: E: Present study; F: Shamsudin (1990); G: Nather-Khan (1990); H: WanMaznah and Mansor (2002); I: Fareha et al. (2011); J: Saifullah et al. (2014); K: Aishah and Nooraida (1994). 
Tabel 2

Revised species identity from plankton surveys previously done in Malaysia.

\begin{tabular}{|c|c|}
\hline Reference & Revision \\
\hline \multicolumn{2}{|l|}{ Nitzschia spp. } \\
\hline $\begin{array}{l}\text { Shamsudin (1990), p. 169, Fig. 8.162; Fig. } \\
\text { 8.164; Fig. } 8.165\end{array}$ & Pseudo-nitzschia sp. \\
\hline Aishah (2005), p. 153, Fig. 11 & Pseudo-nitzschia sp. \\
\hline \multicolumn{2}{|l|}{ N. panduriformis } \\
\hline $\begin{array}{l}\text { Shamsudin Shamsudin (1990), p. 167, Fig. } \\
8.156\end{array}$ & $\begin{array}{l}\text { Psammadictyon } \\
\text { panduriformis }\end{array}$ \\
\hline Fareha et al. (2011), p. 17, Fig. 5(g) & Tryblionella sp. \\
\hline \multicolumn{2}{|l|}{ N. sigma var. inter } \\
\hline Shamsudin (1990), p. 167, Fig. 8.157 & $\begin{array}{l}\text { Identity undetermined } \\
\text { due to poor and } \\
\text { indistinct drawing } \\
\text { illustration. }\end{array}$ \\
\hline \multicolumn{2}{|l|}{ N. sigma var. indica } \\
\hline Shamsudin (1990), p. 167, Fig. 8.158 & $\begin{array}{l}\text { Identity undetermined } \\
\text { due to poor and } \\
\text { indistinct drawing } \\
\text { illustration. }\end{array}$ \\
\hline \multicolumn{2}{|l|}{ N. closterium } \\
\hline $\begin{array}{l}\text { Shamsudin (1990), p. 167, Fig. 8.160; p. } \\
\text { 195, Fig. } 63\end{array}$ & Cylindrotheca sp. \\
\hline Aishah (2005), p. 151, Fig. 8 & Cylindrotheca sp. \\
\hline \multicolumn{2}{|l|}{ N. hungarica } \\
\hline Shamsudin (1990), p. 195, Fig. 64 & Petroneis sp. \\
\hline
\end{tabular}

Regional diatom diversity documentation especially of the genus Nitzschia is important to provide distribution data to ecologists. Several hundreds of Nitzschia species are currently being listed in the online databases (e.g., World Register of Marine Species, Algaebase, etc.), published articles, while some are only available in very old reference materials (e.g., Smith, 1853; Grunow, 1877 etc.) in foreign languages. With emerging number of Nitzschia species being discovered worldwide and progressive research on its taxonomy, many species were tentatively revised and a few of the previous sections/ subgroups had been reclassified into new genera (Round et al., 1990). Most of the listed species in the online database have been verified by the experts (Trobajo et al., 2013).

There are not many available references on tropical distribution of Nitzschia. To name a few are studies done by Cleve (1901), Foged (1971), Archibald (1972), Chin et al. (1986), Aishah and Nooraida (1994) and Alakananda et al. (2012). It is perhaps more conducive to compare species of the same region or similar climate, as geographical and environmental conditions may have influence on the valve shapes and sizes in certain ways (Trobajo et al., 2004; Trobajo et al., 2011). Moreover, some Nitzschia spp. are confined to specific regions (Hasle and Syvertsen, 1997), which could therefore be excluded when examining tropical species. Yet, careful elimination is entailed on Nitzschia species that exhibit cosmopolitism. Illustrations of specimens are also crucial for morphology recognition due to limited access to the type specimens. A bibliography of diatom electron micrographs was compiled by Gaul et al. (1993).

In total, there are 11 species of Nitzschia recorded in Malaysia comprising the freshwater, mangroves and marine habitats (Table 1). These are mostly members of the section Lanceolatae, Nitzschiella and Nitzschia (Table 1). As some small and rare species could have been overlooked during the processes of isolation and acid-treatment, this quantity is adequate if compared to 29 Nitzschia spp. compiled over a century in China (Chin et al., 1986) which also included the fossil records. On the other hand, Foged (1971) documented 10 freshwater Nitzschia spp. from Thailand; while other studies had mainly documented the generic distribution of Nitzschia, attributed to the complexity in the species identification (Alakananda et al., 2012) or lack of interest. Species identification and comparison in this study were selective, as cell dimensions of Nitzschia that were out of range or not belonging to the same group or section was excluded. The Genbank accession numbers are available in (Suriyanti and Gires, in review).

Section Lanceolatae is the largest subgroup that comprises most of Nitzschia species (Mann, 1978). The section's name reflects the outline of the valves. It is dominated by smallsized Nizschia and the valves are finely striated. The raphe system is strongly eccentric. Based on the morphology traits, at least six Nitzschia species in Malaysia are members of this group. Records of $\mathrm{N}$. amabilis, N. frustulum, N. inconspicua and $\mathrm{N}$. pusilla were obtained from this study while $\mathrm{N}$. lanceolatae and $\mathrm{N}$. palea were compiled from secondary data.

N. amabilis is a new name proposed by Suzuki et al. (2010) to replace $\mathrm{N}$. laevis and is thereby synonymous. It is constricted at the centre of the valve outline. The valve shape resembles $\mathrm{N}$. umbilicata Hustedt albeit N. amabilis has a smaller size (Table 1). $\mathrm{N}$. umbilicata is 31? $\mathrm{m}$ in length and 8? $\mathrm{m}$ in width (Foged, 1971). $\mathrm{N}$. amabilis has higher densities of fibulae and striae in 10? $\mathrm{m}$, compared to N. umbilicata which has 8 fibulae and 15 ? 16 striae in 10 ? $\mathrm{m}$ (Foged, 1971). N. amabilis is among common diatom occurring in tropical waters (Foged, 1971).

$\mathrm{N}$. frustulum is euryhaline as there were records of this species in brackish, freshwater as well as marine habitats (Reimer, 1954; Trobajo et al., 2004). While the striae densities of $\mathrm{N}$. frustulum have been constant (26 30 in 10 [? $\mathrm{m}$ ) in Mann (1978) and Trobajo et al. (2013), our specimen has density almost twice as much (Table 1). The fibulae quantity of our specimen agrees with Trobajo et al. (2013), but opposed to Mann (1978) where the fibulae densities of his specimen were lower (8 8 ? 10 in 10 ? $\mathrm{m}$ ). Morphology details and variations of $N$. frustulum were discussed in depth in Trobajo et al. (2013).

$\mathrm{N}$. inconspicua is lacking the wider central interspace of fibulae, despite the presence of central raphe ending. Central raphe ending does not necessarily accompany by the central nodule (Mann, 1978). The cell dimensions of N. inconspicua are comparable to $\mathrm{N}$. invisitata Hustedt and $\mathrm{N}$. soratensis Morales and Vis (refer to Trobajo et al. 2013). Nonetheless, the valve shapes and fibula densities of these species do not agree with each other.

Record of N. lanceolata and N. palea was retrieved from phytoplankton surveys one in Malaysia (Nather-Khan, 1990; Shamsudin, 1990; Wan-Maznah and Mansor, 2002). N. lanceolata is widely distributed in brackish and marine waters of Asia (Chin et al., 1986). Meanwhile, N. palea is usually associated with polluted stream water (Wan-Maznah and Mansor, 2002) and is a tolerant species (Nather-Khan, 1990).

The last member of section Lanceolatae recorded in Malaysia is $\mathrm{N}$. pusilla. It is an estuarine benthic diatom (Trobajo et al., 2011) which has also been recorded in highly organic spring water (Coste and Ricard, 1980). In this study, the density of fibulae and striae of the whole valve were counted as that the total cell length of this species is less than 10 ?m (Table 1). A specimen collected from an estuary in a study done by Fareha et al. (2011) was identified as N. cf. amphibia (Table 1). N. amphibia Grunow has lanceolate-linear valves and blunted ends (Kociolek, 2011c), as opposed to the ovate cell outline of the specimen in (Fareha et al., 2011). Furthermore, the measurements also did not fit into the size range of $\mathrm{N}$. amphibia. $\mathrm{N}$. amphibia has cell dimensions of $14-41 \mu \mathrm{m}$ in length $3.5-5.0 \mu \mathrm{m}$ in width (Hustedt 1930 as cited in Foged (1971); Boyer, 1927; Kociolek, 2011c) but the specimen recorded by Fareha et al. (2011) is $8.5 \mu \mathrm{m}$ long and $2.7 \mu \mathrm{m}$ wide. We had therefore revised the specimen as N. pusilla in accordance with the micrographs and cell dimensions.

The cell of Nitzschia in Section Nitzschiella is characterized by a fusiform outline which extends into elongated rostrum apices (Mann, 1978). N. longissima is one of the most commonly recorded species of this section, though the frequent 
confusions with Cylindrotheca sp. due to their morphology similarities. Cylindrotheca was originated from the genus Nitzschia and had been reclassified as a separate genus by Reimann and Lewin (1964). More often than not, specimens were inaccurately identified as a Nitzschia species. It was listed in Malaysia plankton surveys (Shamsuddin, 1990; Aishah, 2005) as $N$. closterium (Ehrenberg) Smith. N. longissima specimen has been clearly presented in Fareha et al. (2011) along wtih TEM micrographs. Both $N$. longissima and $C$. closterium have a central interspace and elongated rostrate projections in the apices (Hasle and Syvertsen, 1997). The apices of C. closterium are abruptly curved whereas $N$. longissima apices are straight. Perforations in the fusiform part are only observed in $\mathrm{N}$. longissima. The habitats of both species consist of marine, brackish and freshwater environments (Chin et al., 1986). Among other morphologically similar species are $N$. ventricosa Kitton and $N$. acicularis (Kutzing) Smith. However, $N$. ventricosa has a centric raphe system while $N$. acicularis lacks a central interspace and has shorter rostra (Mann, 1978).

Another species in this section is N. lorenziana. The cell is sigmoid in both valve and girdle views; a feature rarely seen in the section Nitzschiella (Mann, 1978). Therefore, this species should be placed in the section Nitzschia (Mann, 1978). The section Nitzschia is a combination of Obtusae and Sigmata sections (Mann, 1978). It may sometimes be referred as section Sigmoidea. The section Nitzschia comprises cells having sigmoid outlines in both valve and girdle views (section Sigmata) (Mann, 1978); and are deflected at the central raphe ending area in those of section Obtusae. The raphe system could be strongly eccentric or less eccentric in some species.

$N$. lorenziana is distributed in intertidal zones and distinct from its variety var. densestriata by the lower density of striae (Chin et al., 1986). The valve outline is similar to N. clausii, apart from $N$. clausii having a central interspace and the raphe central deflects away from the margin. The number striae and fibulae of our specimens are higher compared to other Nitzschia spp. despite its short valves (Table 1). The width is relatively narrow and its apical ends are capitate. Unlike N. paeneperpetua, irregular striae arrangements pattern is not observed at the curvature margins in both $N$. sigma and $N$. lorenziana. Our specimen appeared non-sigmoid in girdle views, contradict to the type species of $N$. lorenziana. However, it could be an artifact as the light microscope images were taken from an aged culture. Until further evidence is obtained, we conclude that our specimen is $N$. lorenziana based on the frustule structures.

The very elongated and rarely recorded species $N$. paeneperpetua was collected from Port Dickson (Table 1). The raphe position of $N$. paeneperpetua is more or less eccentric. A member of section Nitzschia that has extensively elongated valves is N. maxima Grunow. However, a central nodule is absent in N. maxima (Mann, 1978), which differentiates it from $N$. paeneperpetua. Irregular striae arrangement patterns were observed at the margins where the valve is being curved to form a sigmoid. Although $N$. paeneperpetua has many similarities with most species from the section Insignes, this section generally consists of species that have very large cells with coarse fibulae character, which did not fit the description of our specimen.

A specimen identified as N. obtusa Smith was recorded from Sarawak estuary (Fareha et al., 2011). Referring to the micrograph provided in Fareha et al. (2011), the cell has an oblique-truncate shape in valve view and the apices ends are oblique. In the contrary, N. obtusa is described as having a large valve with deflection in the central part and lacks a central interpace (Mann, 1981). Thus, it could be more accurately identified as a variation to its type species, i.e., N. obtusa var. scalpelliformis Grunow based on the features and descriptions.
N. obtusa var. scalpelliformis is taxonomically accepted as a synonym to N. scalpelliformis (Table 1). Similarly, a specimen of $N$. obtusa var. scalpelliformis was incorrectly identified as a Rhizosolenia sp. in Shamsudin (1990) (Table 1).

Another commonly encountered sigmoid species, i.e. N. sigma, differs from its allies by being sigmoid in both valve and girdle views (Mann, 1978). Two variations of $N$. sigma i.e., var. intercedens Grunow and var. indica Karsten were documented in Shamsudin (1990). However, identities of the specimens are in doubt due to poorly drawn illustrations and were therefore omitted from this listing.

Several species from the previous sections of Nitzschia that had been redefined as new genera were constantly reported as Nitzschia spp. in literatures (Shamsudin, 1990; Aishah, 2005). Some of the Nitzschia sections that had been derived as new genera are Pseudo-nitzschia Peragallo (section Pseudonitzschia peragallo), Tryblionella smith (section Tryblionella grunow), and Psammadictyon Mann (section Panduriformes grunow). Yet, scattered information on the re-classifications and obsolete data has led to much confusion. Consequently, many specimens are being inaccurately identified as Nitzschia spp. (Table 2). For instance, Pseudo-nitzschia spp. were reported as Nitzschia spp. (Shamsudin, 1990; Aishah, 2005) while the micrographs were portraying the typical cell-overlapping character of the genus Pseudo-nitzschia. N. panduriformis illustrated in Shamsudin (1990) ought to be renamed as Psammadictyon panduriformis (Gregory) Mann. While N. panduriformis was also listed in Fareha et al. (2011), the identification is dubious as the description of the specimen of having an s-shaped valve contradicts with morphology of $N$. panduriformis. Another genus that frequently confused as Nitzschia due to the similarities in morphology is Hantzschia grunow. These two genera could be differentiated by the valve symmetries (see Round et al. 1990). Persistent inaccuracy in Nitzschia identification indicates the need for proper documentation of the morphology of genus Nitzschia, which reflects the importance of this study.

Previous records of Nitzschia spp. were obtained as part of the phytoplankton surveys conducted in Malaysia (Shamsudin, 1990; Aishah, 2005; Saifullah et al., 2014). Most of the Nitzschia specimens had only been identified to the extent of its generic taxonomy ranking stemmed from limited ability in Nitzschia identification. Furthermore, the surveys done were meant for monitoring the water qualities instead of taxonomic purposes. However, the importance of proper Nitzschia species identification should not be neglected as some of Nitzschia species are toxic (Lundholm and Moestrup, 2000; Thoha et al., 2012; Smida et al., 2014; Suriyanti et al., in press; Suriyanti and Gires, 2015). Comprehensive descriptions and micrographs of Nitzschia spp. could assist in the diatom's identification although the need for less tedious and costly procedures is inevitable.

From our observations, we inferred that only the widths and the presence of central interspaces are constant intraspecies. A useful remark though is that the width of a valve must be measured when the cell lays flat, starting from its central margin to the opposite edge instead of the raphe, which is commonly confused as the valve margin by the novices. Furthermore, the presence of a central nodule does not necessarily accompany by the large central interspace (Mann, 1978 ) as in N. inconspicua and N. navis varingica (Lundholm and Moestrup, 2000; Suriyanti and Gires, 2015). A central nodule is defined as interruption of the raphe slit by thickening of silica in the middle part (Hasle and Syvertson, 1997). The presence of a central interspace must be carefully examined through large volumes of whole valve observations particularly of those with irregular fibulae arrangements. For example, in some of the specimens, wider separation of fibulae in the lower valve 
resembled a central interspace, despite its absence in the upper valve. Further examination of other valves had confirmed the central interspace non-existence. Sometimes, the wider separation of fibulae in the central part of some hypothecae or epithecae was likely due to fibulae arrangement irregularity. The traditional way of counting fibulae and interstriae density seemed to be more reliable (Reimer, 1954). This is true for cells that are less than $10 \mu \mathrm{m}$ in lengths. However, it is not practical in frustules that are finely and densely striated.

The lengths of valve vary greatly amongst Nitzschia species. Thus, length measurements are indefinite variables yet important in Nitzschia identification. We would like to emphasize that the measurement range provided in Table 1 is based on 30 randomly selected valves of first batch of clonal culture to minimize error due to size reduction from mitotic division. The LM images of $N$. lorenziana, $N$. frustulum, $N$. pusilla and $N$. inconspicua were taken on a later date from aged cultures. The variations in shapes and sizes especially in lengths could be partly affected from the different growth stages of the species (Reimer, 1954), which could be distinct from its parental cells (Amato et al., 2005).

\section{Conclusion}

In conclusion, visual interpretations of micrographs are important in Nitzschia species identification. The cell shapes and outlines are one of the main characteristics for section delineation. The presence of the central interspaces is also a stable trait for species identifications. Sizes of valve should not be disregarded as an important feature in Nitzschia species identification as well, although they could very highly variable. In general, the lengths vary more greatly compared to the widths. Specimen observation using a light microscopy is more preferable and easily accessible. Nevertheless, electron microscopy could assist in certain ways particularly in minute features and angular views of the frustules. Tentative sample collections in unexplored sites in Malaysia could add up the number of current Nitzschia spp. collections. Revision of previous documentations of Nitzschia from Malaysia is required to rectify any misleading data.

\section{Acknowledgements}

We thank Dzulhelmi Nasir for his assistance in sample collection. The specimens and slides used for morphology identification in this study were deposited in the Marine Microbes and Biotechnology Laboratory of Universiti Kebangsaan Malaysia (UKM). We thank Dr. Lim Po Teen for providing the Naphrax mountant. Suriyanti was funded by MyBrain15 Scholarship of the Malaysian Ministry of Higher Education and grant 02-01-02-SF0786 awarded to Gires Usup. We acknowledge the staff of UKM VPSEM and FESEM who assisted in the electron microscopy.

\section{References}

Aishah, S., 2005. Phytoplankton. In: Sasekumar, A., and Chong, V.C. editors. Ecology of Klang Strait. University of Malaya Press. Kuala Lumpur, Malaysia. pp. 133-167.

Aishah, S., and Nooraida, A. R., 1994. Diatoms of the River Kanching, Templer Park, Malaysia. Diatom 9: 73-81.

Alakananda, B., Mahesh, M. K., Hamilton, P. B., Supriya, G., Karthick, B., and Ramachandra, T. V., 2012. Two new species of Nitzschia (Bacilariophyta) from Shallow Wetlands of Peninsular India. Phytotaxa. 54: 13-25.
Amato, A., Orsini, L., D'alelio. D., and Montresor, M., 2005. Life cycle, size reduction patterns, and ultra structure of the pennate planktonic diatom Pseudo-nitzschia delicatissima (Bacillariophyceae). J. Phycol. 41: 542556.

Archibald, R. E. M., 1972. A preliminary key to the fresh and brackish water species of the genus Nitzschia. Limnol. Soc. South. Afr. 19: 35-55.

Boyer, 1927. Synopsis of North American Diatomaceae. Part II : Naviculatae, Surirellatae. Proc. Acad. Nat. Sci. Phila. 79: 229-583.

Chin, T. G., Cheng, Z. D., Lin, J. M., and Liu, S. C., 1986. The marine benthic diatoms in China (Vol. I). Ocean Press. Beijing, China.

Chu, W. L., Phang, S. M., and Goh, S. H., 1996. Environmental effects on growth and biochemical composition of Nitzschia inconspicua Grunow. J. Appl. Phycol. 8: 389396.

Cleve, P. T., 1901. Plankton from the Indian Ocean and the Malay Archipelago. K. Svenska Vetenskapsakademiens Handl. 35(5): 1-58.

Cleve, P. T., and Grunow, A., 1880. Beiträge zur Kenntniss der arctischen Diatomeen. K. Svenska Vetenskapsakademiens. Handl. 4. 17(2): 1-121, pls IVII.

Cleve, P. T., and Möller, J. D., 1879. Diatoms. Part IV, No.169-216. Upsala: Esatas Edquists Boktryckeri.

Coste, M., and Ricard, M., 1981. On some interesting finely striated Nitzschiae observed under light and electron microscopes. Systematic and ecological Aspects. In: Ross R, editors. Proceedings of the Sixth Symposium on Recent and Fossil Diatoms. Koenigstein: Otto Koeltz Science Publishers, pp. 191-202.

Fareha, H., Leaw, C. P., and Lim, P. T., 2011. Morphological observation of common pennate diatoms (Bacillariophyceae) from Sarawak estuarine waters. Ann. Microsc. 11: 12-23.

Foged, N., 1971. Freshwater Diatoms in Thailand. Cramer. Lehre, Thailand.

Gaul, U., Geissler, U., Henderson, M., Mahoney. R., and Reimer, C. W., 1993. Bibliography on the fine-structure of diatom frustules (Bacillariophyceae). Proc. Acad. Nat. Sci. Phila, Acad. Nat. Sci. 144: 69-238.

Grunow, A., 1862. Die österreichischen Diatomaceen nebst Anschluss einiger neuen Arten von andern Lokalitäten und einer kritischen Uebersicht der bisher bekannten Gattungen und Arten. Verh. zool.-bot. Ges. Wien 12: 315-472, 545-588. pp. 579.

Guiry, M. D., and Guiry, G. M., 2014. AlgaeBase. National University of Ireland, Galway. Website: http://www.algaebase.org [accessed 27 May 2014].

Hasle, G. R., and Syvertsen, E. E., 1997. Marine diatoms. In: Tomas $\mathrm{CR}$, editor. Identifying marine phytoplankton. Academic Press. USA. pp. 5-361.

Hustedt, F., 1930. Bacillariophyta (Diatomeae). In: (Pascher, editors) Die Süsswasser-Flora Mitteleuropas. Gustav Fischer, Jena. Zweite Auflage. Heft 10: 466 pp., 875 pls.

Hustedt, F., 1939. Die Diatomeenflora des Küstengebietes der Nordsee vom Dollart bis zur Elbemündung. I. Die Diatomeenflora in den Sedimenten der unteren Ems sowie auf den Watten in der Leybucht, des Memmert und bei der Insel Juist. Adhandlungen des Naturwissenschaftlichen Verein zu Bremen 31(2/3): 571-677. 
Iwasaki, H., 1961. The life-cycle of Porphyra tenera in vitro. Biol. Bull. 121: 173-187.

Kaczmarska, I., Fryxell, G. A., and Watkins, T. P., 1986. Effect of two Gulf Stream warm-core rings on distribution patterns of the diatom genus Nitzschia. Deep Sea Research Part A. Oceanogr. Res. Pap. 33(11-12): 18431868.

Kociolek, P., 2011a. Nitzschia inconspicua. Diatoms of the United States.

Website: http://westerndiatoms.colorado.edu/taxa/species/nit zschia_inconspicua (accessed 16 December 2015).

Kociolek, P., 2011b. Nitzschia sigma. Diatoms of the United States.

Website: http://westerndiatoms.colorado.edu/taxa/species/nit zschia sigma (accessed 19 December 2015).

Kociolek, P., 2011c. Nitzschia amphibia. Diatoms of the United States. Website: http://westerndiatoms.colorado.edu/taxa/species/nit zschia_amphibia (accessed 22 December 2015).

Lundholm, N., and Moestrup, O., 2000. Morphology of the marine diatom Nitzschia navis-varingica sp. nov. (Bacillariophyceae), another producer of the neurotoxin domoic acid. J. Phycol. 36: 1162-1174.

Mann, D. G., 1978. Studies in the Family Nitzschiaceae (Bacillariophyta) Vols 1 and 2. Ph.D. dissertation, University of Bristol. Bristol, UK. pp. 386.

Mann, D. G., 1981. A new species of sigmoid Nitzschia (Bacillariophyta). Israel. J. Bot. 30(1): 1-10.

Nather-Khan, I. S. A., 1990. Assessment of water pollution using diatom community structure and species distribution a case study in a Tropical River Basin. Int. Rev. Hydrobiol. 75(3): 317-338.

Pritchard, A., 1861. A History of Infusoria, Including the Desmidiaceae and Diatomaceae, British and Foreign. Whittaker and Co., Ave Maria Lane. London, U.K.

Reimann, B. E. F., and Lewin, J. C., 1964. The diatom genus Cylindrotheca Rabenhorst. J. Roy. Micr. Soc, Series 3 83(3): 283-296.

Reimer, C. W., 1954. Re-evaluation of the diatom species Nitzschia frustulum (Kutz.) Grun. Butler University Botanical Studies 11. Indianapolis, U.S.

Renberg, I., 1990. A procedure for preparing large sets of diatom slides from sediment cores. J. Paleolimnol. 4: 87-90.

Rivera, P., and Cruces, F., 2011. First report for Chile of the marine diatoms Nitzschia amabilis, Nitzschia elegantula and Chaetoceros muelleri var. subsalsum. Rev. Biol. Mar. Oceanogr. 46(1): 95-99.

Round, F. E., Crawford, R. M., and Mann, D. G., 1990. The Diatoms: Biology and morphology of the genera. Cambridge University Press. New York, USA.

Saifullah, A. S. M., Abu Hena, M. K., Idris, M. H., Halimah, A. R., and Johan, I., 2014. Diversity of phytoplankton from mangrove estuaries of Sarawak, Malaysia. World. Appl. Sci. J. 31(5): 915-924.

Shamsudin, L., 1990. Diatom marin di perairan Malaysia. Percetakan Dewan Bahasa dan Pustaka. Kuala Lumpur, Malaysia.

Shi, J., Pan, K. H., Wang, X. Q., Chen, F., Zhou, M., Zhu, B. H., and Qing, R. W., 2008. Hierarchical recognition on the taxonomy of Nitzschia closterium f. minutissima. Chin. Sci. Bull. 53(2): 245-250.
Smida, D. B., Lundholm, N., Kooistra, W. H. C. F., Sahraoui, I., Ruggiero, M. V., Kotaki, Y., Ellegaard, M., Lambert, C., Mabrouk, H. H., and Hlaili, A. S., 2014. Morphology and molecular phylogeny of Nitzschia bizertensis sp. nov. a new domoic acid-producer. Harmful. Algae. 32: 4963.

Smith, W., 1853. A Synopsis of the British Diatomaceae; with remarks on their structure, functions and distribution; and instructions for collecting and preserving specimens. John van Voorst, Paternoster Row.

Smith., 1856. Synopsis of British Diatomaceae. John Van Voorst Vol. 2. London, UK.

Suriyanti, S. N. P., Dzulhelmi, M. N., and Gires, U., Screening of toxic marine Nitzschia species (Bacillariophyceae) in Malaysia. Am Inst Physics Con Proc. In press.

Suriyanti, S. N. P., and Gires, U., 2015. First report of the toxigenic Nitzschia navis--varingica (Bacillariophyceae) isolated from Tebrau Straits, Johor, Malaysia. Toxicon. 108: 257-263.

Suriyanti, S. N. P., and Gires, U. Morphology and molecular phylogeny of Nitzschia dentata sp. nov. and $N$. johorense sp. nov. (Bacillariophyceae) from Malaysia. In review.

Suzuki, H., Nagumo, T., and Tanaka, J., 2010. Nitzschia amabilis nom. nov., a new name for the marine species $N$. Laevis Hustedt. Diatom. Res. 25(1): 223-224.

Thoha, H., Kotaki, Y., Panngabean, L., Lundholm, N., Ogawa, H., Lim, P. T., Takata, Y., Kodama, M., and Fukuyo, Y., 2012. Screening of diatoms that produce ASP toxins in southernmost Asian waters. Coast. Mar. Sci. 35(1): 3438

Torgan, L. C., Salomoni, S. E., and Bicca, A. B., 2009. Diatomáceas Sobre Limnoperna fortunei (Dunker), molusco introduzido no lago guaíba, sul do Brasil. Rev. Bras. Bot. 32(1): 23-31.

Trobajo, R., Clavero, E., Chepurnov, V. A., Sabbe, K., Mann, D. G., Ishihara, S., and Cox, E. J., 2009. Morphological, genetic and mating diversity within the widespread bioindicator Nitzschia palea (Bacillariophyceae). Phycologia. 48(6): 443-459.

Trobajo, R., Cox, E. J., and Quintana, X. D., 2004. The Effects of some environmental variables on the morphology of Nitzschia frustulum (Bacillariophyta), in relation to its use as a bioindicator. Nova. Hedwigia. 79: 433-445.

Trobajo, R., Rovira, L., Ector, L., Wetzel, C. E., Kelly, M., and Mann, D. G., 2013. Morphology and identity of some ecologically important small Nitzschia species. Diatom. Res. 28(1): 37-59.

Trobajo, R., Rovira, L., Mann, D. G., and Cox, E. J., 2011. Effects of salinity on growth and on valve morphology of five estuarine diatoms. Phycol. Res. 59(2): 83-90.

Wan Maznah, W. O., and Mansor, M., 2002. Aquatic pollution assessment based on attached diatom communities in the Penang River Basin, Malaysia. Hydrobiol. 487: 229241.

Wen, Z. Y., and Chen, F., 2001. Optimization of Nitrogen sources for heterotrophic production of Eicosapentaenoic Acid by the diatom Nitzschia laevis. Enzyme. Microb. Tech. 29: 341-347. 